\title{
Kompetensi Account Officer dan Informasi Asimetri terhadap Kinerja Murabahah dengan Risiko sebagai Variabel Intervening (Studi di BMT Kabupaten Banyuwangi dan Jember)
}

\author{
(The Competency of Account Officer and Asymmetry Information to \\ Murabahah Performance with Risk as Intervening Variable \\ (Study in BMT Banyuwangi and Jember Regency))
}

\author{
Brian Ahmad Nur Hasan, Ahmad Roziq, Imam Mas'ud ${ }^{1}$ \\ Jurusan Akuntansi, Fakultas Ekonomi dan Bisnis, Universitas Jember (UNEJ) \\ Jln. Kalimantan 37, Jember 68121 \\ E-mail:imammasud@yahoo.co.id
}

\begin{abstract}
Abstrak
Penelitian ini bertujuan untuk menguji pengaruh kompetensi account officer syariah dan informasi asimetri terhadap kinerja pembiayaan murabahah dengan risiko pembiayaan murabahah sebagai variabel intervening. Sampel penelitian ini menggunakan sampel BMT di Kabupaten Banyuwangi dan Jember. Penelitian ini menggunakan Partial Least Square (PLS) dengan purposive sampling 51 responden. Hasil penelitian menunjukkan kompetensi account officer syariah berpengaruh positif signifikan terhadap variabel kinerja pembiayaan murabahah. Informasi asimetri berpengaruh negatif signifikan terhadap variabel kinerja pembiayaan murabahah. Selanjutnya kompetensi account officer syariah tidak berpengaruh terhadap variabel risiko pembiayaan murabahah. Informasi asimetri tidak berpengaruh terhadap variabel risiko pembiayaan murabahah. Dan terakhir risiko pembiayaan murabahah berpengaruh negatif secara siginifikan terhadap variabel kinerja pembiayaan murabahah.
\end{abstract}

Kata Kunci: Kompetensi account officer syariah, Infomasi Asimetri, Risiko Pembiayaan Murabahah, Kinerja Pembiayaan Murabahah.

\begin{abstract}
The aim of this research were to examine the influence of syariah account officer competency and asymmetry information for murabahah budgeting performance by using murabahah budgeting risk as intervening variable. The research sample was the BMT in Banyuwangi and Jember regency. This research used Partial Least Square (PLS) with purposive sampling 51 respondents. The Results showed is syariah account officer competency was significant positively influence on the murabahah budgeting performance variable. Asymmetry information was significant negatively influence on the murabahah budgeting performance. So, syariah account officer competency was not influence on the murabahah budgeting risk variable. Fourth, asymmetry information was not influence on the murabahah budgeting risk. And last, murabahah budgeting risk was insignificant negatively influence on the murabahah budgeting performance.
\end{abstract}

Keywords: Syariah account officer competency, asymmetry information, risk of murabahah financing, and performance of murabahah financing.

\section{Pendahuluan}

Pertumbuhan ekonomi dalam pembangunan nasional tidak terlepas dari peran serta sektor lembaga keuangan baik itu dari perbankan maupun lembaga keuangan non-bank. Di sisi lain, pertumbuhan ekonomi sekarang ini juga diikuti dengan signifikannya perkembangan lembaga keuangan syariah di Indonesia walaupun ini merupakan lembaga keuangan yang masih baru. Menurut data BPS tahun 2012, jumlah unit usaha mikro yang kurang lebih $90 \%$ dari semua total unit usaha yang ada, maka sangat memungkinkan lembaga keuangan syariah untuk bisa tumbuh lebih besar lagi. Keberhasilan lembaga keuangan syariah di tanah air tidak bisa dilepas dari peran Lembaga Keuangan Mikro Syariah (LKMS). Kedudukan LKMS yang antara lain dipresentasikan oleh
Baitul Maal wal Tamwil (BMT), dan Koperasi Pesantren (Kopontren) sangatlah vital dalam menjangkau transaksi syariah di daerah yang tidak bisa tercakup oleh pelayanan bank - bank umum yang konvensional dan bank-bank umum yang membuka unit syariah.

Salah satu LKMS yang berkembang dengan cukup cepat saat ini yaitu BMT. Keberadaan BMT ini merupakan usaha untuk memenuhi keinginan khususnya sebagian umat Islam yang menginginkan jasa layanan bank syariah untuk mengelola perekonomiannya dan pengembangan ekonomi masyarakat yang tidak terjamah oleh lembaga keuangan makro seperti bank. Baitul Maal wat Tamwil memiliki dua jenis kegiatan operasional yang dilakukan. Pertama, sebagai penghimpun dana zakat, infaq dan sodaqoh yang selanjutnya disalurkan ke 8 asnaf yang telah dijelaskan dalam Al-Quran. Kedua, BMT

1) Corresponding author

e-Journal Ekonomi Bisnis dan Akuntansi, 2017, Volume IV (1) : 12-18 
adalah untuk menghimpun dana umat yang kemudian akan disalurkan dan diinvestasikan ke berbagai produk pembiayaan yang ada di BMT dan hasil yang diperoleh akan dibagikan ke anggota BMT.

Berlatarbelakang permasalahan tersebut maka peneliti ingin mengkaji dan meneliti variabel-variabel yang berpengaruh terhadap kinerja pembiayaan murabahah. Tujuan studi ini dilakukan yakni untuk mengetahui, mengkonfirmasi, dan menguji variabel yang berpengaruh. Selanjutnya peneliti mengambil tiga variabel yang berpengaruh terhadap kinerja pembiayaan murabahah yaitu kompetensi account officer syari'ah, informasi asimetri, dan risiko pembiayaan murabahah. Diharapkan nantinya hasil dari studi ini bisa meningkatkan kinerja pembiayaan murabahah dan mengurangi risiko-risiko yang terjadi dalam akad pembiayaan murabahah sehingga dengan meningkatnya kinerja pembiayaan berarti meningkatkan peranan ilmu akuntansi pada pelaksanaan pembiayaan berbasis non-bagi hasil.

Wei and Weidong (2002) menjelaskan bahwa kompetensi adalah pengetahuan, skill dan kemampuan serta karakter yang berhubungan dengan kinerja efektif yang tinggi. Oleh karena itu, kompetensi mempunyai pengaruh nyata terhadap kinerja dan menjadi salah satu penentu kinerja perusahaan. Semakin tinggi kompetensi karyawan dalam hal ini account officer, maka berdampak besar terhadap semakin meningkatnya kinerja pembiayaan perusahaan karena mereka mampu menyeleksi nasabahnya serta mengambil keputusan terhadap pemberian pembiayaan yang sesuai dengan hasil yang diharapkan.

Setiap usaha yang dijalankan baik perseorangan maupun bersama-sama pasti memiliki risiko sesuai dengan jenis usaha yang dibidanginya. Adanya ketidakpastian akan masa depan yang harus dihadapi oleh manajer sangatlah perlu untuk di manage dengan menggunakan manajamen risiko. Penerapan manajemen risiko dapat bervariasi antara satu bank dengan bank lain, sesuai dengan tujuan, kebijakan usaha, dan kompleksitas usaha serta kemampuan bank dalam hal keuangan, infrastruktur pendukung maupun sumber daya manusia (Arifin, 2006:63). Dengan target nasabah adalah pengusaha mikro dan masyarakat biasa, BMT sangat rentan dengan ketidakpastian keberlangsungan kondisi keuangan para nasabahnya. Menurut Karim (2004, 251), risiko pembiayaan bisa timbul karena analisis pembiayaan yang keliru dilakukan karyawan BMT (account officer). Untuk mengurangi risiko ini, manajemen BMT memerlukan staf yang terlatih dan berpengalaman agar risiko bisa diminimalisir serendah mungkin.

Dalam teori keagenan, hubungan agensi muncul ketika satu orang atau lebih (principal) memperkerjakan orang lain (agent) untuk memberikan suatu jasa dan kemudian mendelegasikan wewenang pengambilan keputusan kepada agent tersebut. Hubungan antara principal dan agent dapat mengarah pada kondisi ketidak-seimbangan informasi (asymmetrical information) karena agent berada pada posisi memiliki informasi yang lebih banyak tentang suatu usaha dibanding principal. Hal ini tentu akan berpengaruh terhadap terjadinya manajemen laba apabila agent tersebut bertindak secara individu untuk memaksimalkan kepentingan diri sendiri. Ali (2007) menjelaskan bahwa banyak faktor seperti information asymmetry, agency problem, dan human capital deficiency yang menimbulkan risiko ketidkastabilan pada perbankan.

Harri dan Raviv (1990 dalam Roziq, 2007) menguji hubungan antara informasi asimetri dan model keagenan. Temuannya menyimpulkan bahwa munculnya informasi asimetri dapat mempengaruhi besar kecilnya pendapatan investasi yang diperoleh. Informasi asimetri antara pihak BMT dengan nasabah dapat diklasifikasikan ke dalam dua bentuk yaitu adverse selection dan moral hazard. Ketika pihak nasabah melakukan salah satu dari kedua bentuk informasi tersebut maka akan menyebabkan informasi yang dibutuhkan oleh BMT terkait analisis terhadap nasabah menjadi berkurang. Ahmed (2005 dalam Roziq, 2007) menjelaskan bahwa transparansi mengurangi moral hazard dan adverse selection meningkatkan efisiensi serta integritas pasar dan memperkuat disiplin pasar. Dari pernyataan tersebut dengan berkurangnya tingkat informasi asimetri antara pihak BMT dan nasabah bisa meningkatkan transparansi dan kinerja pembiayaan.

Risiko pembiayaan murabahah merupakan risiko timbulnya kerugian akibat kegagalan/ketidakmampuan nasabah atau pembeli dalam memenuhi kewajiban sesuai akad atau perjanjian yang telah ditetapkan antara penjual dan pembeli. Hubungan pengaruh antara risiko dengan kinerja dijelaskan oleh Gizycki (2001) bahwa return on asset (ROA) suatu bank dipengaruhi oleh risiko kredit dan semakin tinggi risiko dapat mengurangi profitabilitas bank. Menurut Arifin (2006:121) manajemen bank harus secara simultan mempertimbangkan berbagai risiko yang akan berpengaruh pada perubahan tingkat laba yang diperoleh. Karena risiko kredit, terjadi ketidakpastian net-income dan market value of equity disebabkan karena tidak ada pembayaran dan penundaan pembayaran baik pokok maupun bunga (Ahmed, 2005). Hal ini menjelaskan bahwa apabila suatu BMT mampu mengelola risikonya dengan baik akan meningkatkan tingkat laba yang bisa diperoleh sehingga bisa meningkatkan kinerja BMT tersebut. Permasalahan yang dibahas dalam penelitian ini adalah sebagai berikut: (a) apakah kompetensi account officer syariah berpengaruh positif terhadap kinerja pembiayaan murabahah?, (b) apakah informasi asimetri berpengaruh negatif terhadap kinerja pembiayaan murabahah?, (c) apakah kompetensi account officer syariah berpengaruh negatif terhadap risiko pembiayaan murabahah?, (d) apakah informasi asimetri berpengaruh positif terhadap risiko pembiayaan murabahah?, dan (d) apakah risiko pembiayaan murabahah berpengaruh negatif terhadap kinerja pembiayaan murabahah?

\section{Metode}

Penelitian ini menggunakan pendekatan kuantitatif. Pada penelitian in jenis data yang digunakan adalah data subyek karena menggunakan data subyek karena menggunakan kuesioner dalam memperoleh datanya dengan meneliti opini responden. Adapun sumber data yang digunakan dalam penelitian ini adalah data primer yang diperoleh dengan cara menyebarkan kuesioner kepada manajer BMT pada BMT di Kabupaten Banyuwangi dan Jember. Populasi dalam penelitian ini adalah seluruh BMT yang ada di Kabupaten Banyuwangi berjumlah 23 kantor dan BMT yang ada di 
Kabupaten Jember berjumlah 33 kantor. Variabel penelitian yang digunakan dalam penelitian ini adalah:

Variabel eksogen yang terdiri dari dua variabel yaitu kompetensi account officer syariah (KAOS) dan informasi asimetri (IA).

Variabel endogen yang terdiri dari dua variabel yaitu risiko pembiayaan murabahah (RPM) sebagai variabel endogen intervening dan kinerja pembiayaan murabahah (KPM) sebagai variabel endogen tergantung.

Penelitian ini menganalisis data dengan metode kuantatif. Analisis yang digunakan pada penelitian ini terdiri dari analisis deskriptif untuk melihat gambaran karakteristik populasi dan analisis jalur. Analisis jalur digunakan untuk pengujian hipotesis dengan menggunakan Partial Least Square (PLS). Adapun analisis dalam penelitian ini menggunakan software SmartPLS.

\section{Hasil dan Pembahasan}

Adapun Populasi dalam penelitian ini adalah seluruh BMT (Baitul Maal wa Tamwil) yang berada di Kabupaten Banyuwangi dan Jember. Pemilihan sampel dengan menggunakan metode purposive sampling, yaitu peneliti kemungkinan memiliki target atau tujuan tertentu dalam memilih sampel secara tidak acak. Adapun kriteria dalam metode purposive sampling dengan yaitu BMT yang pernah melaksanakan akad murabahah dan memiliki otoritasasi dalam pengambilan keputusan pembiayaan. Sehingga total sampel yang diteliti setelah dilakukan sampling berjumlah total 51 kantor dengan 21 kantor di Kabupaten Banyuwangi dan 30 kantor di Kabupaten Jember.

Hasil analisis deksriptif meliputi seluruh variabel penelitian yaitu variabel kompetensi account officer syariah, informasi asimetri, risiko pembiayaan murabahah dan kinerja pembiayaan murabahah yang dilakukan untuk mengetahui kondisi riil persepsi responden terhadap indikator dari masing-masing variabel.

\section{Tabel 1}

Hasil Analisis Deskriptif Variabel KAOS

\begin{tabular}{cccc}
\hline & \multicolumn{3}{c}{ Persentase Indikator } \\
\cline { 2 - 4 } & Pengetahuan & Ketrampilan & Sikap \\
\hline 1 & 0 & 0 & 0 \\
\hline 2 & 1.96 & 8,0 & 1.96 \\
\hline 3 & 72,54 & 27,45 & 37,25 \\
\hline 4 & 23,53 & 58,82 & 49,02 \\
\hline 5 & 1,96 & 5,88 \\
\hline & Rerata Indikator dan Rerata Variabel \\
\hline Rerata Indikator & 3,45 & 3,63 \\
\hline Rerata Variabel & $\mathbf{3 , 6 6}$ \\
\hline
\end{tabular}

Dari tabel 1 nampak bahwa jika dilihat dari masing-masing indikator kompetensi, nilai indikator pengetahuan di bawah nilai 4 sebesar 74,5\%, nilai indikator ketrampilan di atas 4 sebesar $65 \%$ dan nilai indikator sikap di atas 4 sebesar $61 \%$. Oleh karena itu manajemen BMT perlu meningkatkan kompetensi account officer syariah terutama di bagian pengetahuan dalam menangani pembiayaan murabahah.
Pengetahuan account officer syariah yang menangani pembiayaan murabahah yang perlu ditingkatkan adalah berkaitan dengan tingkat pendidikan, pengetahuan dan pemahaman account officer tentang pembiayaan murabahah.

Tabel 2

Hasil Analisis Deskriptif IA

Skor

Persentase Indikator

Adverse Selection

Moral Hazard

\begin{tabular}{ccc}
\hline 1 & 23,53 & 23,52 \\
\hline 2 & 52,94 & 50,98 \\
\hline 3 & 19,61 & 21,57 \\
\hline 4 & 3,92 & 3,92 \\
\hline 5 & 0 & 0 \\
\hline
\end{tabular}

Rerata Indikator dan Rerata Variabel

\begin{tabular}{ccc}
\hline $\begin{array}{c}\text { Rerata } \\
\text { Indikator }\end{array}$ & 2,04 & 2,22 \\
\hline
\end{tabular}

Rerata Variabel

2,13

Selanjutnya melihat dari tabel 2, presentase pada dua indikator di bawah yang memiliki nilai informasi asimetri yang rendah karena rata-rata nilai di bawah 3, maka bisa dijelaskan kalau informasi asimetri antara pihak BMT dan nasabah cukup rendah bahkan di beberapa BMT juga sangat rendah mengingat pembiayaan murabahah ini merupakan pembiayaan yang marginnya tetap sehingga apabila terjadi ketimpangan informasi maka tidak terlalu besar.

Tabel 3

Hasil Analisis Deskriptif RPM

\begin{tabular}{|c|c|c|c|c|}
\hline \multirow[t]{2}{*}{ Skor } & \multicolumn{4}{|c|}{ Persentase Indikator } \\
\hline & $\begin{array}{c}\text { Risiko } \\
\text { Pembiayaan } \\
\text { yang } \\
\text { Dibiayai }\end{array}$ & $\begin{array}{c}\text { Risiko } \\
\text { Berkurangnya } \\
\text { Nilai } \\
\text { Pembiayaan } \\
\text { Murabahah }\end{array}$ & $\begin{array}{c}\text { Risiko } \\
\text { Karakter } \\
\text { Buruk } \\
\text { Nasabah }\end{array}$ & $\begin{array}{c}\text { Risiko } \\
\text { yang } \\
\text { Timbul dari } \\
\text { Lemahnya } \\
\text { Analisis } \\
\text { BMT }\end{array}$ \\
\hline 1 & 0 & 17,65 & 9,8 & 11,76 \\
\hline 2 & 45,10 & 43,14 & 58,52 & 56,86 \\
\hline 3 & 45,10 & 35,3 & 29,41 & 27,45 \\
\hline 4 & 9,8 & 3,92 & 1,96 & 3,92 \\
\hline 5 & 0 & 0 & & 0 \\
\hline \multicolumn{5}{|c|}{ Rerata Indikator dan Rerata Variabel } \\
\hline $\begin{array}{l}\text { Rerata } \\
\text { Indikator }\end{array}$ & 2,65 & 2,52 & 2,54 & 2,24 \\
\hline $\begin{array}{c}\text { Rerata } \\
\text { Variabel }\end{array}$ & & 2,49 & & \\
\hline
\end{tabular}

Berdasarkan Tabel 3 nampak bahwa risiko pembiayaan murabahah rata-rata memiliki nilai di bawah 3 (risiko pembiayaan murabahah sedang). Namun untuk nilai indikator e-Journal Ekonomi Bisnis dan Akuntansi, 2017, Volume IV (1) : 12-18 
risiko pembiayaan yang dibiayai masih di atas nilai 3 sebesar $54,90 \%$, dan nilai indikator lainnya rata-rata di bawah 3 . Hal ini menunjukkan bahwa perlunya manjemen BMT untuk menekan risiko terutama risiko eksternal seperti karakter dan kondisi para nasabahnya.

Tabel 4 menunjukkan bahwa kinerja pembiayaan murabahah rata-rata memiliki nilai di atas 4 (kinerja pembiayaan murabahah tinggi). Namun untuk indikator tingkat keuntungan masih di bawah 4 dengan nilai sebesar 62,74, sedangkan nilai lainnya masih di atas 4 . Hal ini menunjukkan manajemen BMT perlu meningkatkan keuntungan terhadap produk pembiayaan murabahah.

\section{Tabel 4}

Hasil Analisis Deskriptif KPM

\begin{tabular}{|c|c|c|c|c|c|c|}
\hline \multirow[t]{2}{*}{ Skor } & & \multicolumn{5}{|c|}{ Persentase Indikator } \\
\hline & $\begin{array}{l}\text { Terhind } \\
\text { ar dari } \\
\text { Riba, } \\
\text { Gharar } \\
\text { \&Mais } \\
\text { yir }\end{array}$ & $\begin{array}{c}\text { Rasa } \\
\text { Damai }\end{array}$ & $\begin{array}{c}\text { Tingkat } \\
\text { Keuntung } \\
\text { an }\end{array}$ & $\begin{array}{c}\text { Pertumbuha } \\
n \\
\text { Pembiayaan } \\
\text { Murabahah }\end{array}$ & $\begin{array}{c}\text { Pertum } \\
\text { buhan } \\
\text { Nasaba } \\
\text { h }\end{array}$ & $\begin{array}{c}\text { Kontrib } \\
\text { usi } \\
\text { Zakat }\end{array}$ \\
\hline 1 & 0 & 1,96 & 0 & 0 & 0 & 0 \\
\hline 2 & 5,88 & 1,96 & 1,96 & 0 & 0 & 15,69 \\
\hline 3 & 17,65 & 21,57 & 60,78 & 37,25 & 35,29 & 27,45 \\
\hline 4 & 56,86 & 54,90 & 35,29 & 47,06 & 52,94 & 47,06 \\
\hline \multirow[t]{2}{*}{5} & 19,61 & 19,61 & 1,96 & 15,69 & 11,76 & 9,8 \\
\hline & \multicolumn{6}{|c|}{ Rerata Indikator dan Rerata Variabel } \\
\hline $\begin{array}{l}\text { Rer } \\
\text { ata } \\
\text { Indi } \\
\text { kato } \\
\mathrm{r}\end{array}$ & 3,9 & 3,88 & 3,37 & 3,78 & 3,76 & 3,51 \\
\hline \multicolumn{4}{|c|}{ Rerata Variabel } & \multicolumn{3}{|c|}{3.7} \\
\hline
\end{tabular}

Selanjutnya dalam penelitian ini outer moel atau model pengukuran dengan indikator reflektif dievaluasi dengan menggunakan uji convergent validity dan discriminant validity untuk pengujian validitas data. Sedangkan uji reliabilitas data menggunakan composite reliability. Masingmasing uji outer model dianalisis dan dijelaskan di bawah ini.

\section{Convergent validity}

Convergent validity dari model pengukuran dengan indikator reflektif dinilai berdasarkan korelasi antara item score/component score dengan construct score yang dihitung dengan PLS. ukuran reflektif individual dikatakan tinggi jika berkorelasi lebih dari 0,7 dengan konstruk yang ingin diukur (Ghozali, 2014). Namun untuk loading 0,50 sampai 0,60 masih dapat diterima dengan melihat output korelasi antara indikator dengan konstruknya. Korelasi itu dilihat dari $\mathrm{T}$ statistik outer loading $>1,964$.

Berdasarkan perhitungan yang dilakukan dengan menggunakan software SmartPLS maka indikator kompetensi account officer syariah berupa KAOS 1 dan KAOS 3 masingmasing memiliki loading faktor sebesar 0,755 dan 0,876 dengan nilai T-statistik sebesar dan 4,820 dan 8,461 sehingga kedua indikator kompetensi account officer syariah berupa KAOS 1 dan KAOS 3 valid untuk mengkonstruk variabelnya karena memiliki loading factor diatas 0,7 dan nilai T-statistik diatas 1,964 .
Berdasarkan perhitungan yang dilakukan dengan menggunakan software SmartPLS maka indikator informasi asimetri berupa IA 1 dan IA 2 memiliki nilai loading faktor sebesar 0,865 dan 0,934 dan nilai T-statistik sebesar 5,338 dan 10,223. semua indikator informasi asimetri berupa IA 1 dan IA 2 memiliki loading factor diatas 0,7 dan T-statistik diatas 1,964 sehingga indikator informasi asimetri valid untuk mengkonstruk variabelnya.

Berdasarkan perhitungan yang dilakukan dengan menggunakan software SmartPLS maka indikator risiko pembiayaan murabahah berupa RPM 2, RPM 3 dan RPM 4 dengan masing-masing memiliki nilai loading faktor sebesar $0.800,0.762$ dan 0.805 serta memiliki nilai T-statistik sebesar 7,407, 6,067 dan 7,334. Maka indikator risiko pembiayaan murabahah yang valid untuk mengkonstruk variabel risiko pembiayaan murabahah adalah ketiga indikator diatas.

Berdasarkan erhitungan yang dilakukan dengan menggunakan software SmartPLS maka indikator kinerja pembiayaan murabahah berupa KPM 1, KPM 2, KPM 4 dan KPM 5 dengan masing-masing memiliki nilai loading faktor sebesar $0,762,0,817,0,845$ dan 0,791 dan nilai T-statistik sebesar 9,533, 11,776, 20,127 dan 14,486. Sesuai dengan hasil nilai tersebut maka indikator kinerja pembiayaan murabahah yang valid untuk mengkonstruk variabel kinerja pembiayaan murabahah adalah keempat indikator kinerja pembiayaan murabahah diatas.

\section{Discriminant Validity}

Discriminant validity dari model pengukuran dengan indikator reflektif dinilai berdasarkan cross loading pengukuran dengan konstruk. Jika korelasi konstruk dengan item pengukuran lebih besar daripada ukuran konstruk lainnya, maka hal ini menunjukkan bahwa konstruk laten memprediksi ukuran pada blok mereka sendiri lebih baik daripada ukuran pada blok lainnya.

Berdasarkan perhitungan yang dilakukan dengan menggunakan software SmartPLS maka nilai korelasi konstruk informasi asimetri (IA) dengan indikatornya sebesar 0,865 dan 0,934 lebih tinggi dibandingkan korelasi indikator informasi asimetri (IA) dengan konstruk lainnya. Pada korelasi konstruk kompetensi account officer syariah (KAOS) memiliki nilai korelasi dengan indikatornya sebesar 0,755 dan 0,876 juga lebih tinggi apabila dibandingkan dengan dengan korelasi KAOS terhadap konstruk lainnya. Korelasi kontruk risiko pembiayaan murabahah (RPM) dengan indikatornya sebesar $0,800,0,762$ dan 0,805 ternyata lebih tinggi jika dibandingkan dengan korelasi antara indikator RPM dengan konstruk lainnya. Hal yang sama juga terjadi pada korelasi konstruk Kinerja Pembiayaan Murabahah (KPM) dengan indikatornya dengan nilai 0,762 , $0,817,0,845$ dan 0,791 yang lebih tinggi apabila dibandingkan dengan korelasi kontruk KPM dengan indikator konstruk lainnya.

\section{Composite Reliability}

Uji reliabilitas yang digunakan di dalam studi ini adalah composite reliability $(\rho c)$. Instrumen penelitian untuk mengukur sebuah variabel memiliki composite reliability yang baik jika memiliki composite reliability $\geq 0,7$ 
Berdasarkan perhitungan yang dilakukan dengan menggunakan software SmartPLS maka nilai composite reliability konstruk informasi asimetri (IA) sebesar 0.895 . Nilai composite reliability konstruk kompetensi account officer syariah (KAOS) sebesar 0.800. Nilai composite reliability konstruk risiko pembiayaan murabahah (RPM) sebesar 0.832. Sedangkan nilai composite reliability konstruk kinerja pembiayaan murabahah (KPM) sebesar 0.880. Semua konstruk memiliki nilai composite reliability lebih besar dari 0,70. Hal ini menunjukkan bahwa informasi asimetri (IA), kompetensi account officer syariah (KAOS), risiko pembiayaan murabahah (RPM) dan kinerja pembiayaan murabahah (KPM) memiliki reliabilitas yang baik.

\section{Analisis Jalur}

\section{Uji Goodness-Fit Model}

Pengujian terhadap model struktural dilakukan dengan melihat nilai R-square yang merupakan uji goodness-fit model.

Tabel 5

R-Square

\begin{tabular}{cc}
\multicolumn{2}{c}{ R-Square } \\
\hline Kompetensi Account officerSyariah \\
\hline \multicolumn{2}{c}{ R Square } \\
\hline Informasi Asimetri \\
\hline Risiko Pembiayaan Murabahah \\
\hline Kinerja Pembiayaan Murabahah & 0.037 \\
\hline
\end{tabular}

Dari tabel 5 di atas diketahui bahwa model pengaruh variabel kompetensi account officer syariah (KAOS) dan informasi asimetri (IA) terhadap risiko pembiayaan murabahah (RPM) memberikan nilai R-square sebesar 0.037 yang dapat diinterpretasikan bahwa variabilitas risiko pembiayaan murabahah dapat dijelaskan oleh variabilitas kompetensi account officer syariah dan informasi asimetri hanya sebesar 3,7 \% sedangkan 96,3\% dijelaskan oleh variabel lain diluar yang diteliti.

Model pengaruh variabel kompetensi account officer syariah (KAOS), informasi asimetri (IA) dan risiko pembiayaan murabahah (RPM) memberikan nilai R-square sebesar 0.422 yang dapat diinterpretasikan bahwa variabilitas kinerja pembiayaan murabahah dapat dijelaskan oleh variabilitas kompetensi account officer syariah, informasi asimetri dan risiko pembiayaan murabahah sebesar $42,2 \%$ sedangkan 57,8 $\%$ dijelaskan oleh variabel lain diluar yang diteliti.

\section{Uji Hipotesis}

Tabel 6

\section{Path Coefficient}

\begin{tabular}{lccccc}
\hline & $\begin{array}{c}\text { Original } \\
\text { Sample } \\
(\mathrm{O})\end{array}$ & $\begin{array}{c}\text { Sample } \\
\text { Mean } \\
(\mathrm{M})\end{array}$ & $\begin{array}{c}\text { Standard } \\
\text { Error } \\
\text { (STERR) }\end{array}$ & $\begin{array}{c}\mathrm{T} \\
\text { Statistics } \\
(\mathrm{O} / \mathrm{STER} \\
\mathrm{R})\end{array}$ & $\begin{array}{c}\text { Keputusa } \\
\mathrm{n}\end{array}$ \\
\hline $\begin{array}{l}\text { Kompetensi Account } \\
\text { officerSyariah }\end{array}$ & 0,271 & 0,272 & 0,109 & 2,487 & Signifikan \\
$\begin{array}{l}->\text { Kinerja } \\
\text { Pembiayaan }\end{array}$ & & & & & \\
Murabahah & & & & & \\
\hline $\begin{array}{l}\text { Informasi Asimetri } \\
->\text { Kinerja }\end{array}$ & $-0,284$ & $-0,281$ & 0,118 & 2,403 & Signifikan \\
$\begin{array}{l}\text { Pembiayaan } \\
\text { Murabahah }\end{array}$ & & & & & \\
\hline
\end{tabular}

\begin{tabular}{llllll}
\hline $\begin{array}{l}\text { Kompetensi Account } \\
\text { officerSyariah } \\
->\text { Risiko }\end{array}$ & $-0,125$ & $-0,128$ & 0,235 & 533 & $\begin{array}{c}\text { Tidak } \\
\text { Signifikan }\end{array}$ \\
$\begin{array}{l}\text { Pembiayaan } \\
\text { Murabahah }\end{array}$ & & & & & \\
\hline $\begin{array}{l}\text { Informasi Asimetri } \\
\text { - Risiko }\end{array}$ & 0,095 & 0,130 & 0,251 & 0,377 & $\begin{array}{c}\text { Tidak } \\
\text { Signifikan }\end{array}$ \\
$\begin{array}{l}\text { Pembiayaan } \\
\text { Murabahah }\end{array}$ & & & & & \\
\hline $\begin{array}{l}\text { Risiko Pembiayaan } \\
\begin{array}{l}\text { Murabahah } \\
\text { - K Kinerja }\end{array}\end{array}$ & $-0,349$ & $-0,367$ & 0,091 & 3,823 & Signifikan \\
$\begin{array}{l}\text { Pembiayaan } \\
\text { Murabahah }\end{array}$ & & & & & \\
\hline
\end{tabular}

Berdasarkan hasil sebagaimana tabel 6 di atas maka bisa dijelaskan bahwa informasi asimetri (IA) berpengaruh positif secara tidak signifikan terhadap risiko pembiayaan murabahah (RPM) dimana koefisiennya sebesar 0,095 dan nilai T-statistik sebesar 0,377. Kompetensi account officer syariah (KAOS) berpengaruh positif secara signifikan terhadap kinerja pembiayaan murabahah (RPM) dengan koefisien sebesar 0,271 dan nilai T-statistik sebesar 2,487. Informasi asimetri (IA) berpengaruh negatif secara signifikan terhadap kinerja pembiayaan murabahah (KPM) dengan koefisien sebesar $-0,284$ dan nilai T-statistik sebesar 2,403. Risiko pembiayaan murabahah (RPM) berpengaruh negatif secara signifikan terhadap kinerja pembiayaan murabahah (KPM) dengan nilai koefisien sebesar $-0,349$ dan nilai $\mathrm{T}$ statistik sebesar 3,823.

\section{Pengaruh Kompetensi Account officer Syariah terhadap Kinerja Pembiayaan Murabahah}

Berdasarkan hasil pengujian keofisien jalur pada Tabel 5, penelitian ini menghasilkan temuan bahwa variabel kompetensi account officer syariah berpengaruh positif secra signifikan terhadap kinerja pembiayaan murabahah dengan koefisien sebesar 0,271 dan signifkan dengan T-statistik sebesar 2,487. Hubungan ini menunjukkan bahwa semakin rendah kompetensi account officer syariah di bagian pembiayaan murabahah akan berpengaruh semakin rendah juga kinerja pembiayaan murabahah. Sebaliknya apabila semakin tinggi kompetensi account officer syariah mempengaruhi semakin tinggi pula kinerja pembiayaan murabahah pada BMT di kabupaten Banyuwangi dan Jember. Penelitian ini mendukung penelitian Ismail (2005) yang mengungkapkan bahwa secara empirik terjadi hubungan yang signifikan antara kompetensi sumberdaya manusia dengan pengukuran kinerja baik pada perusahaan yang berbasis pengetahuan tinggi maupun rendah. Penelitian yang dilakukan oleh roziq (2007) dan iswahyudi (2013) yang melakukan survei terhadap pembiayaan mudharabah menunjukkan bahwa kompetensi account officer syariah berpengaruh positif siginifikan terhadap kinerja pembiayaan mudharabah.

Pengaruh Informasi Asimetri terhadap Kinerja Pembiayaan Murabahah

Berdasarkan hasil pengujian keofisien jalur pada Tabel 5, penelitian ini menghasilkan temuan bahwa variabel informasi asimetri berpengaruh negatif terhadap variabel kinerja pembiayaan murabahah dengan koefisien sebesar -0,284 dan nilai T-statistik sebesar 2,403. Hubungan ini menunjukkan bahwa semakin rendah informasi asimetri antara BMT

e-Journal Ekonomi Bisnis dan Akuntansi, 2017, Volume IV (1) : 12-18 
dengan nasabah akan mempengaruhi menjadi semakin tingginya kinerja pembiayaan murabahah. Sebaliknya jika tingkat informasi asimetri tinggi akan mempengaruhi kinerja pembiayaan murabahah menjadi semakin rendah. Temuan penelitian ini mendukung Harri dan Raviv (1990, dalam Roziq) yang menguji hubungan antara informasi asimetri dan model keagenan yang menyimpulkan bahwa munculnya informasi asimetri dapat mempengaruhi besar kecilnya pendapatan investasi yang diperoleh. Agent melakukan manipulasi dengan menggunakan dana yang telah diperoleh guna memaksimalkan kepentingan diri sendiri sehingga pihak tersebut menyembunyikan beberapa informasi yang tidak diketahui principal. Akhirnya principal seringkali dalam posisi seperti ini jelas tidak diuntungkan. Penelitian ini juga mendukung oleh penelitian yang dilakukan oleh dan Roziq (2007) dan Iswahyudi (2013) yang keduanya menghasilkan kesimpulan bahwa variabel informasi asimetri berpengaruh negatif signifikan terhadap kinerja pembiayaan murabahah.

Pengaruh Kompetensi Account officer Syariah terhadap Risiko Pembiayaan Murabahah.

Berdasarkan hasil pengujian koefisien jalur pada Tabel 5, penelitian ini menghasilkan temuan bahwa variabel kompetensi account officer syariah tidak berpengaruh terhadap risiko pembiayaan murabahah dengan koefisien sebesar -0,125 dan tidak signifikan dengan nilai T-statistik sebesar 0,533. Hal ini disebabkan karena variabilitas kompetensi account officer syariah tidak mampu mempengaruhi variabilitas risiko pembiayaan murabahah. Meskipun kompetensi account officer syariah tidak mempengaruhi risiko kinerja pembiayaan, namun sebenarnya kompetensi account officer syariah mempengaruhi secara signifikan terhadap kinerja pembiayaan murabahah sebagai variabel endogen. Temuan dari penelitian ini tidak mendukung penelitian sebelumnya yang dilakukan oleh iswahyudi (2013) yang melakukan survei terhadap BMT di Kabupaten Jember yang menunjukkan hasil bahwa kompetensi account officer di BMT berpengaruh signifikan positif terhadap kinerja pembiayaan murabahah.

Pengaruh Informasi Asimetri terhadap Risiko Pembiayaan Murabahah.

Berdasarkan hasil pengujian keofisien jalur pada Tabel 5, penelitian ini menghasilkan temuan bahwa variabel informasi asimetri (IA) tidak berpengaruh terhadap risiko pembiayaan murabahah (RPM) dimana koefisiennya sebesar 0,095 dan tidak signifikan dengan nilai T-statistik sebesar 0,377 . Hal ini disebabkan karena variabilitas informasi asimetri tidak mampu mempengaruhi variabilitas risiko pembiayaan murabahah. Meskipun informasi asimetri tidak mempengaruhi risiko kinerja pembiayaan, namun sebenarnya informasi asimetri mempengaruhi secara signifikan terhadap kinerja pembiayaan murabahah sebagai variabel endogen.

Pengaruh Risiko Pembiayaan Murabahah terhadap Kinerja Pembiayaan Murabahah

Berdasarkan hasil pengujian keofisien jalur pada Tabel 5, penelitian ini menghasilkan temuan bahwa variabel risiko pembiayaan murabahah berpengaruh negatif secara signifikan terhadap variabel kinerja pembiayaan murabahah dengan koefisien sebesar -0,349 dan nilai T-statistik sebesar 3,823. Hubungan ini menunjukkan bahwa dengan semakin tingginya tingkat risiko yang terdapat dalam pembiayaan murabahah bepengaruh dengan semakin rendahnya kinerja pembiayaan murabahah. Sebaliknya jika tingkat risiko dalam pembiayaan murabahah rendah maka berpengaruh terhadap semakin tingginya kinerja pembiayaan murabahah. Temuan penelitian ini mendukung adanya hubungan pengaruh antara risiko dengan kinerja yang dijelaskan oleh Gizycki (2001) bahwa return on asset (ROA) suatu bank dipengaruhi oleh risiko kredit dan semakin tinggi risiko bisa mengurangi profitabilitas suatu bank. Fahrul (2012) juga menjelaskan bahwa risiko pembiayaan murabahah berpengaruh terhadap profitabilitas bank syariah. Roziq (2007) yang meneliti pengaruh risiko pembiayaan terhadap kinerja pembiayaan menghasilkan temuan bahwa risiko pembiayaan mudharabah berpengaruh negatif signifikan terhadap kinerja pembiayaan mudharabah.

\section{Simpulan}

Kompetensi account officer syariah berpengaruh positif secara signifikan terhadap kinerja pembiayaan murabahah. Secara teoritis temuan ini menjelaskan bahwa kompensi account officer syariah sangat berperan penting melalui pengetahuan, kemampuan dan sikap dalam meningkatkan kinerja pembiayaan terutama pembiayaan murabahah. Studi ini juga mendukung teori kompetensi yang menjelaskan perlunya peningkatan kompetensi sumber daya manusia di perbankan syariah sehingga mampu mendorong kesungguhan dalam melaksanakan tanggung jawab sehingga menciptakan kinerja yang terbaik. Sehingga hipotesis satu (H1) dari penelitian ini diterima dengan arah positif signifikan.

Informasi asimetri berpengaruh negatif secara signifikan terhadap kinerja pembiayaan murabahah. Temuan ini menunjukkan bahwa informasi asimetri sangat berperan penting dalam meningkatkan kinerja pembiayaan murabahah. Informasi yang terjadi pada suatu BMT mampu mempengaruhi besar kecilnya pendapatan investasi yang diperoleh. Ketika informasi yang seharusnya bisa didapatkan BMT gagal diperoleh maka profitabilitas bisa menurun dan juga melemahkan kinerja dari BMT tersebut. Sehingga hipotesis dua $(\mathrm{H} 2)$ dari penelitian ini diterima dengan arah negatif signifikan.

Kompetensi account officer syariah tidak berpengaruh terhadap risiko pembiayaan murabahah. Temuan ini menjelaskan bahwa kompetensi account officer syariah tidak mampu mempengaruhi tingkat risiko pembiayaan murabahah. Sehingga hipotesis tiga (H3) dari penelitian ini ditolak.

Informasi asimetri tidak berpengaruh terhadap risiko pembiayaan murabahah. Temuan ini menjelaskan bahwa informasi asimetri tidak mampu mempengaruhi rendah atau tingginya tingkat risiko pembiayaan murabahah. Sehingga hipotesis empat $(\mathrm{H} 4)$ dari penelitian ini ditolak.

Risiko pembiayaan murabahah berpengaruh negatif secara signifikan terhadap kinerja pembiayaan murabahah. Keberlangsungan dan pertumbuhan BMT sebagian bergantung pada kemampuan BMT mengelola risiko berkaitan dengan pembiayaan BMT. Didukung pula oleh Syed Jaafar Azanan bahwa kesuksesan perbankan syariah pada masa depan sangat kepada efektivitas Bank dalam mengelola risiko. Tingkat risiko yang tinggi jelas akan berpengaruh terhadap kinerja pembiayaan yang berisiko pula 
pada profitabilitas pembiayaan. Sehingga hipotesis lima (H5) dari penelitian ini diterima dengan arah negatif signifikan.

\section{Referensi}

Arifin, Zainul. 2006. Dasar-dasar Manajemen Bank Syari'ah. Jakarta: Pustaka Alfabet.

Aziz, Amin. 2004. Pedoman Pendirian BMT. Jakarta: Pinbuk Press.

Chowdhury M. A. 1996. Examining the Theory of the Firm in IPE and IE. Chapter 17. Kegan Paul International.

Fahrul, Arfan, dan Darwanis. 2012. Pengaruh Tingkat Risiko Pembiayaan Musyarakah dan Pembiayaan Murabahah terhadap Tingkat Profitabilitas Bank Syariah. Jurnal Akuntansi Pascasarjanan. Banda Aceh: Universitas Syiah Kuala

Ghozali, Imam. 2014. Structural Equation Modeling Metode Alternatif dengan Partial Least Square. Semarang :Universitas Diponegoro Semarang.

Gizycki, Marianne. 2001. The Effect of Macroeconomic Conditions on Bank Risk and Profitability System Stability. Discusion Paper. Department Reserve Bank of Australia Research.

Ismail, Ahmad. 2005 Menggagas Bisnis Islami. Gema Insani Press: Jakarta.

Iswahyudi, A. 2013.Pengaruh kompetensi account officer syariah terhadap kinerja pembiayaan Mudharabah dengan risiko pembiayaan sebagai variabel intervening pada BMTdi Kabupaten Jember. Skripsi, Fakultas Ekonomi, UNEJ.

Karim, A. 2001. Perbankan Syari'ah: Peluang, Tantangan dan Strategi Pengembangan. Jurnal Agama, Filsafat dan sosial.

Maria, S., Ika, N., dan Hisamuddin, N. 2013. Pengembangan Model Reduksi Resiko dan Eskalasi Kinerja Pembiayaan Mudharabah pada Lembaga Keuangan Mikro Syariah. Jember: Universitas Jember.
Muhammad. 2002. Bank Syari'ah: Analisis Kekuatan, Kelemahan, Peluang dan Ancaman. Edisi Kedua. Yogyakarta: Ekonesia Fakultas Ekonomi UII.

Roziq, Ahmad. 2007. Pengaruh Kompetensi Account officer Syariah dan Etika Bisnis Islam terhadap Kinerja Pembiayaan Mudharabah melalui informasi asimetri serta risiko pembiayaan Murabahah pada bank syari'ah di Jawa Timur. Disertasi, Fakultas Ekonomi, UNAIR.

Rahmawati, Suparno, Y., dan Qomariyah, N. 2007. Pengaruh Informasi asimetri terhadap Praktik Manajemen Laba pada Perusahaan Perbankan Publik yang Terdaftar di Bursa Efek Jakarta. Dipublikasikan Jurnal Riset Akuntansi Indonesia Vol. 10, No. 1, hlm 68-89.

Setiabudi, Hendry Y dan Iwan Triyuwono. 2002. Akuntasi Ekuitas. Malang: Salemba Empat.

Susilo, Musa Hubeis dan Budi Purwanto. 2012. Pengaruh Karakteristik dan Perilaku UKM, serta Sistem Pembiayaan terhadap Penyaluran Pembiayaan BNI Syariah. Jurnal Manajemen ISSN: 2058-8418. Bogor: IPB.

Triyuwono, Iwan. 2004. Trust (amanah), The Divine Symbol: Interpretations in the Context of Islamic Banking and Accounting Practices. AsiaPacific Interdiciplinary Research in Accounting Singapore.

Triyuwono, Iwan. 2006. Perspektif, Metodologi dan Teori Akuntansi Syari'ah. Jakarta: PT. RajaGrafindo Persada.

Yumanita, Ascarya Diana. 2005. Mencari Solusi Rendahnya Pembiayaan Bagi-Hasil di Perbankan Syari'ah Indonesia. Buletin Ekonomi Moneter dan Perbankan:8-50. Jakarta: Bank Indonesia.

Wei, Zhang dan Zhong Weidong. 2002. College Student's Performance Appraisal Based on Profesional Competency: an Example of Human Resource Management. Business Management Postdoctoral Mobile Station. Xiamen University. 